\title{
TERRORISMO X PRINCÍPIO DA LEGALIDADE: OS REFLEXOS DO DIREITO PENAL DO INIMIGO NA LEI N. 13.260/16
}

\section{TERRORISM X PRINCIPLE OF LEGALITY: THE CONSEQUENCES OF CRIMINAL LAW OF THE ENEMY AT THE LAW N. 13.260/16}

\author{
Ana Claudia da Silva Abreu ${ }^{1}$ \\ Guilherme Schroeder Abreu ${ }^{2}$
}

\begin{abstract}
RESUMO
$\mathrm{O}$ artigo trata do crime de terrorismo, sobretudo as condutas criminosas previstas na Lei n. 13.260/16. A demanda mundial, após os atentados terroristas de 11 de setembro de 2001, ocorrido nos Estados Unidos, é pela adoção de medidas voltadas à luta contra tal criminalidade. As legislações antiterror normalmente inserem-se no contexto do denominado Direito Penal do inimigo. Entretanto, é necessário analisar o princípio da legalidade como um limite à criminalização, para definir o fenômeno terrorista nas sociedades democráticas. Adota-se o método monográfico e, enquanto técnica de pesquisa, a documentação indireta, notadamente pesquisa bibliográfica.
\end{abstract}

Palavras-chave: Terrorismo; Direito penal do inimigo; Legislação antiterrorismo; Princípio; da Legalidade; Lei n. 13.260/16.

\begin{abstract}
The article deals with the crime of terrorism, particularly the criminal conduct introduced by law number 13.260/16. The global demand after the terrorist attacks of September 11, 2001, occurred in the United States, there is the adoption of legislative measures aimed at combating such crime. The anti-terror laws usually falls within the context of so-called Criminal Law of the enemy. However, it is necessary to analyze the principle of legality as a limit of criminalization, to set the terrorist phenomenon in the context of democratic societies. It was adopted the monographic method, while technical research, the indirect documentation.
\end{abstract}

Keywords: Terrorism; Criminal law of the enemy; Antiterrorism legislation; Principle of legality; Law number 13.260/16.

\footnotetext{
${ }^{1}$ Mestre em Direito do Estado pela Universidade Federal do Paraná - UFPR. Professora da Faculdade Campo Real Guarapuava - Paraná (Brasil). Email: anaclaudia.silva@ gmail.com.

${ }^{2}$ Mestre em Direito do Estado pela Universidade Federal do Paraná - UFPR. Professor da Faculdade Campo Real Guarapuava - Paraná (Brasil). Email: prof.guilhermeabreu@gmail.com.
} 


\section{INTRODUÇÃO}

No início do milênio, sobretudo em face dos ataques terroristas aos Estados Unidos e a vários países europeus surge uma importante questão: o Direito Penal até então estruturado daria conta dessa nova realidade e desse novo perigo? O terrorismo, então, ocupa uma posição central nas discussões relativas ao Direito Penal Internacional. É nesse contexto que a doutrina nacional há muito tempo já apontava a necessidade, sobretudo em razão da internacionalização da questão, da tipificação dos comportamentos que devem ser tidos como criminosos, para um melhor enfretamento do problema. A Lei n. 13.260/2016 veio, finalmente, atender à necessidade de tipificação do crime de terrorismo.

Como uma resposta às exigências da sociedade globalizada e supranacional e com a finalidade combater o terrorismo, surge o Direito penal do inimigo, advogando o incremento do poder punitivo. Assim, altera-se a ótica penal do indivíduo (modelo tradicional) para o sistema, de modo a fundamentar a pena na busca da (re)afirmação da norma, vendo o delito enquanto uma violação disfuncional ao sistema. A sociedade é polarizada - cidadãos x inimigos - estruturandose um Direito penal bélico conformado nas funções atribuídas à pena (prevenção social), na antecipação das proibições penais (da punibilidade), na relação entre o sujeito e o Estado (pessoa e não pessoa) e, como conseqüência, na relação processual penal que será estabelecida entre o Estado-juiz e o sujeito-réu (restrição das garantias).

Cumpre-se que a novel legislação seja observada em consonância ao Estado Democrático de Direito e, mais especificamente ao atendimento à legalidade estrita, sobretudo em relação aos princípios estritamente relacionados com a tipificação das condutas: as garantias da taxatividade, da materialidade da ação e da proporcionalidade.

Diante disso, o trabalho será dividido em quatro partes. Inicialmente, a análise do Direito penal do inimigo, sua origem, base teórica e principais características. Em um segundo momento, fundamental a inferência à legalidade estrita, como um garantia vinculante do processo de criminalização das condutas. Depois, será preciso o estudo do terrorismo no Direito brasileiro para, finalmente, realizar as considerações críticas da Lei n. 13.260/16.

Serão apresentadas algumas apreciações aos tipos penais definidos na lei do terrorismo, contrapondo-os com o princípio da legalidade estrita e avaliando-os pela perspectiva do Direito penal do inimigo, propondo uma reflexão objetiva sobre os limites da intervenção punitiva. Empregar-se-á, para tanto, o método dedutivo, através de análises fundamentais e qualitativas, tendo como recursos bibliografia nacional e estrangeira. 


\section{DIREITO PENAL DO INIMIGO}

A ciência penal sempre foi analisada através de sistemas fechados, calcados na separação da Dogmática Penal das demais ciências criminais - Política Criminal e Criminologia, tidas então como mera auxiliares. O Direito penal é uma ciência essencialmente jurídica e, portanto, sistemática. A Política Criminal, por sua vez, vem a apreciar o Direito existente sob o ponto de vista da repressão do crime de modo a indicar os meios mais adequados para a consecução desse fim; tem o seu lugar ao lado do Direito penal. Precisa, pois, de uma criminologia que investigue os fatores do crime. (LISZT, 2003, p. 29-30)

Esse estudo estanque é superado pela visão de Claus Roxin ${ }^{3}$ quando passa a associar os fins da Política Criminal e os relacionar com a teoria do delito e da pena, com o escopo de resolver os problemas não solucionados pelo formalismo do causalismo e pela fenomenologia do finalismo. As teorias funcionalistas, nascidas dessa percepção de que o Direito Penal tem necessariamente uma missão e que seus institutos (delito e pena) devem ser compreendidos segundo ela, ganham força na década de 70 .

São duas as principais correntes funcionalistas: o funcionalismo teleológico de Claus Roxin, segundo o qual a finalidade do Direito Penal é a "proteger os bens jurídicos do indivíduo e da coletividade contra riscos socialmente intoleráveis" (ROXIN, 2008, p. 71); e o funcionalismo sistêmico, de Günther Jakobs - que visualiza como fim do Direito Penal a proteção da norma para assegurar a vigência do sistema que é ameaçada pelo inimigo.

Para o presente artigo interessa avaliar o funcionalismo radical ou sistêmico de Günther Jakobs do qual decorre a doutrina do direito penal do inimigo.

Referida teoria é construída de forma gradativa. Em um primeiro momento, o autor exibe uma visão crítica do Direito Penal alemão, apresentando nítida preocupação com o que chamou de direito penal do inimigo como um discurso penal de exclusão. Depois, é possível notar uma sutil mudança em seu enfoque, marcado pela descrição das características da doutrina. Por fim, haja vista os ataques terroristas ocorridos nos Estados Unidos, na Inglaterra e na Espanha, a impressão é que "o desenvolvimento da tese de Jakobs nos tempos mais recentes não deixa dúvida acerca de

\footnotetext{
3 "Em face destas construções, a proposta sistemática teleológica/político criminal (funcionalista), que desde 1970 encontra um número crescente de seguidores, realiza uma verdadeira revolução copernicana. A imputação objetiva, ao considerar a ação típica de um risco não permitido dentro do alcance do tipo, estrutura o delito à luz da função do direito penal. Esta teoria utiliza-se de valorações constitutivas da ação típica (risco não permitido, alcance do tipo), abstraindo de suas variadas manifestações ônticas". (ROXIN, 2008, p. 79-80)
} 
que, além de mera descrição, considera legítimo um Direito penal do inimigo em determinadas circunstâncias". (MELLIÁ, 2008, p. 277)

Foi em 1985, na Jornada de Professores de Direito Penal em Frankfurt am Main, que Günther Jakobs, "tentou fixar limites materiais à 'criminalização no estádio prévio à lesão a bem jurídico"” (GRECO, 2005, p. 80) por meio dos arquétipos contrapostos direito penal do inimigo e direito penal do cidadão.

Criticando a doutrina penal tradicional, fundada no conceito aberto de bem jurídico, e censurando, sobretudo, vários tipos penais do Código Penal Alemão (verdadeiras antecipações da tutela penal), o autor defendeu que o Estado, através do Direito penal, com o escopo de garantir a eficácia da norma e combater perigos transforma os seus cidadãos em inimigos. Alertou, ainda, que a doutrina do bem jurídico é que levaria à ausência de limites do Estado penal, pois "sob o conceito amorfo de bem jurídico tudo poderia ser acolhido e, assim, tornar-se suspeito de lesão social, em desrespeito à esfera de liberdade do destinatário do direito, garantida pelo princípio do Estado de Direito Liberal”. (BUNG, 2006, p. 113)

Quando retoma a teoria, em 1999, observa-se uma sutil mudança em seu discurso, que passa a uma fase descritiva, na qual apresenta os critérios caracterizadores da doutrina: a) a punição antecipada, fundada na periculosidade do indivíduo (inimigo); b) a desproporcionalidade das penas (penas severas); c) a flexibilização das garantias; d) o uso exacerbado da lei penal como ferramenta de combate à criminalidade (enfoque combativo).

Em 2003, Jakobs escreveu o texto "Direito penal do cidadão e direito penal do inimigo", no qual, balizado em um direito subjetivo de segurança dos cidadãos, defende que a atuação interventiva penal serve ao combate de perigos. Aquele que "não presta uma segurança cognitiva suficiente de um comportamento pessoal, não só não pode esperar ser tratado como pessoa, mas o Estado não deve tratá-lo como pessoa, (...) do contrário vulneraria o direito à segurança das demais pessoas". (JAKOBS, 2007, p. 42)

Partindo da constatação de que a sociedade moderna é uma sociedade de riscos, uma sociedade emergencial, "extremamente tecnologizada, massificada e global, onde a ação humana se revela suscetível de produzir riscos, também eles globais" (SILVA, 2004, p. 75) vislumbra a necessidade de uma mudança na intervenção penal.

O Direito penal, em razão desse estado de emergência e dessa sociedade de riscos, é arquitetado em dois modelos antagônicos: o Direito penal do cidadão - liberal e garantidor - e o Direito penal do inimigo - emergencial e voltado à prevenção de riscos. Trata-se de uma forma de pensar a estrutura penal a partir de cidadãos, inseridos em uma estrutura jurídica de um Estado de 
Direito e o inimigo, colocado em um local extrajurídico, assim por dizer, um retorno ao estado de natureza $^{4}$, um inimigo que deve ser neutralizado. (GRECO, 2005, p. 86)

A construção teórica do direito penal do inimigo tem direta ligação com a noção de sistemas sociais de LUHMANN (1996, p. 94-95), segundo a qual as expectativas comportamentais normativas "têm que se imunizadas contra um certo grau de contradições ao nível fático, e têm que poder ser vinculáveis a justificativas cognitivamente plausíveis para desapontamentos. (...) ". A premissa luhmanniana pode ser verificada na transferência das expectativas sociais para o Direito penal: as interações humanas criam expectativas entre seus agentes - indivíduos - as quais são normatizadas para que então sejam estabilizadas.

O sistema jurídico é um sistema fechado, portanto, o que significa dizer que "se produz e se reproduz por ele mesmo". (TAVARES, 2000, p. 70) Nesse sistema fechado, as expectativas normativas encontram no sistema seus marcos delimimatores: a vigência da norma depende da confiança em sua vigência a qual só existe a partir do momento em que é construída a expectativa de que a norma não é sistematicamente frustrada.

A primeira característica do direito penal do inimigo é a antecipação da punibilidade ${ }^{5}$, seja pela preferência à tipificação de crimes de perigo (abstrato em sua maioria) e tipos de mera conduta, seja pela punibilidade dos atos preparatórios. Para combater e prevenir os perigos, o direito penal "deve antecipar em muito o seu momento de intervenção, para atingir a mais otimizada proteção de bens jurídicos”. (NEUMANN, 2007, p. 168)

A pena cumpre funções distintas: no Direito penal do cidadão "a função manifesta da pena é a contradição, isto é, a confirmação comunicativa de uma norma infringida, enquanto que no Direito penal do inimigo a função é a eliminação de um perigo, isto é, seu combate mediante a coação jurídica". (POLIANO-ORTIS, 2014, p. 81)

\footnotetext{
${ }^{4}$ Resumidamente podem-se destacar os seguintes fundamentos iusfilosóficos da teoria: visão contratualista do enlace social, baseada na autonomia da vontade e na união da vontade geral, de modo que o malfeitor que ataca o direito social deixa de ser membro do Estado, posto que se encontra em guerra contra este, como demonstra a pena pronunciada contra ele (Rosseau); quem abandona o contrato perde todos os seus direitos como cidadão e como ser humano, passando a um estado de ausência completa de direitos (Fichte); a violação da norma representa um retorno ao estado de natureza e, enquanto tal, seu transgressor merece ser tratado como inimigo/traidor (Hobbes); e, finalmente, quem não aceita o "estado comunitário legal” deverá ser expelido, devendo ser tratado como pessoa e sim como um inimigo (Kant). (JAKOBS, 2005, p. 25-30)

${ }^{5}$ Como Jakobs abdica da ideia de bem jurídico e em seu lugar coloca a validez da norma como o fim do Direito penal, muda-se o ponto de referência: do fato cometido para o fato futuro, através de um amplo adiantamento da punibilidade (prescinde da violação a algum bem jurídico), a transgressão da norma em si justifica a reação penal, vez que pena reafirma a confiança dos cidadãos ao sistema demonstrando as consequências penais da sua violação. Por essa razão, a pena exerce uma função de prevenção geral positiva: evita que os demais membros violem a norma, reafirma a norma violada e assim, previne riscos e novos delitos. Ainda, as penas passam a ser desproporcionalmente altas, exatamente para coibir a transgressão da norma. (MELLIÁ, 2008, p. 57)
} 
Como bem destaca PRITTWITZ (2004, p. 42-43): “(...) é preciso dizer que é visivelmente a intenção de Günther Jakobs salvar a característica de Estado de Direito no direito penal do cidadão, dividindo o Direito penal hoje em vigor num Direito penal parcial 'do cidadão' e um 'direito parcial do inimigo'."

Dessa concepção - pessoa versus inimigo - decorre que ao inimigo, além de lhe ser recusado o status de pessoa, negam-se todos os direitos inerentes a essa condição, ou seja, do rompimento do contrato social decorre a sua suspensão em relação ao transgressor.

Opera-se, portanto, a despersonalização do inimigo - não pessoa. Quem são esses inimigos? "É inimigo quem se afasta de modo permanente do Direito e não oferece garantias cognitivas de que vai continuar fiel à norma”. (JAKOBS, 2007, p. 36)

A pessoa, por sua vez, é definida a partir da expectativa de comportamento fiel à norma e ao direito - destinatária de expectativas normativas. Assim, nega-se o direito e o status de pessoa àqueles que não se comportam em conformidade com o direito e que não fornecem "a garantia mínima cognitiva de comportamento pessoal”. (BUNG, 2006, p. 123)

O direito penal do inimigo é marcado, ainda, pelo enfoque extremamente combativo da lei penal, ou seja, seu uso como uma ferramenta de combate à (nova) criminalidade, diretamente relacionada com a modernidade e a sociedade de riscos. Estruturada está, portanto, a teoria do delito segundo referida doutrina, composta por tipos penais que prescindem de violação concreta ao bem jurídico (crimes de perigo abstrato, formais e de mera conduta) e cujo enfoque está nos comportamentos que violam determinado papel social.

\section{3 (RE)VISITANDO O PRINCÍPIO DA LEGALIDADE}

Tarefa árdua é a definição de delito. Passando por uma conceituação legal - crime é o que a lei diz ser crime; pela análise material de delito (lesão ou perigo de lesão a um bem jurídico); chegou-se, finalmente, ao conceito estratificado ou analítico de crime ${ }^{6}$. Independente da corrente analítica escolhida há uma certeza: a tipificação de uma conduta nada mais é um do um juízo de valor, ou melhor, de desvalor, segundo o qual se elegem determinados fenômenos à categoria de infração penal (crime ou contravenção).

${ }^{6} \mathrm{O}$ conceito analítico de delito é integrado por variadas correntes, bipartidas - fato típico e ilícito; tripartidas - fato típico, ilícito e culpável (podendo a culpabilidade, a depender da corrente, ser substituída pela punibilidade); e até mesmo quadripartidas - fato típico, ilícito, culpável e punível. 
Considerando, ainda, que não há crime sem lei anterior que o defina e que a eleição de determinados comportamentos como condutas criminosas é uma convenção legal, de suma importância o papel do princípio da legalidade no Direito penal e, sobretudo, como um limite à expansão da tutela penal, para que evite que determinadas condutas sejam eleitas à categoria de delito ou que sejam descriminalizadas, por razões de mera conveniência.

"Só as leis podem decretar as penas dos delitos, e esta autoridade só pode residir no legislador, que representa toda a sociedade unidade por um contrato social”. (BECCARIA, 1991. p. 44). O princípio da legalidade penal realiza seu papel político através da circunscrição da potestade punitiva por intermédio da reserva legal na distribuição estatal das funções conferidas ao Estado (divisão dos poderes), incumbindo ao legislador estabelecer os tipos e as penas, e não aos demais poderes (soberania popular). Dessa forma, cumpre seu significado jurídico - a exigência da observância do Estado Democrático de Direito.

Para muito além da legalidade formal ou mera legalidade - lei em sentido estrito, escrita, estrita, formalmente válida (reserva legal) e anterior ao fato (anterioridade) - requer-se a legalidade material ou estrita, "que exige todas as demais garantias como condições necessárias da legalidade penal” (FERRAJOLI, 2002, p. 93) - reserva absoluta de lei.

A criação de crimes independente de lei permite que juízos de valor como anormalidade ou periculosidade do réu sejam suficientes para identificar um delito, inspiram, assim, modelos penais de legalidade atenuada em que é permitida a analogia in malam partem, os tipos penais de autor, a pena eminentemente preventiva (caráter terapêutico, curativo), os quais dão ensejo à legitimação de modelos de Direito Penal máximo.

Fundamental, portanto, a análise do princípio da legalidade com fulcro no paradigma garantista, apresentando-se o princípio da legalidade estrita, conforme assevera FERRAJOLI (2002, p. 349) como “a garantia estrutural que diferencia o direito penal no Estado de 'direito' do direito penal dos Estados simplesmente 'legais', nos quais o legislador é onipotente e, portanto, são válidas todas as leis vigentes, sem nenhum limite substancial à primazia da lei”.

Enquanto o princípio da mera legalidade exige a reserva de lei (dimensão formal) o princípio da estrita legalidade (dimensão material) requer a reserva absoluta de lei, ou seja, "uma norma dirigida ao legislador para que observe a taxatividade (clareza na formulação legal) e a precisão empírica (as desviações escolhidas para merecerem a sanção penal devem ser fática e empiricamente demonstráveis)" (PINHO, 2006, p. 83), e que também avalie a gravidade do delito, a partir do dano causado, na fabricação da norma penal incriminadora. 
Da estrita legalidade decorrem algumas garantias que são fundamentais quando da análise de um tipo penal: certeza (princípio da taxatividade ou da determinação taxativa); verificabilidade da acusação (princípio da materialidade da ação); e punição racional e razoável, em conformidade com a gravidade do delito (princípio da proporcionalidade).

O princípio da taxatividade diferencia a mera legalidade da legalidade estrita, impõe que os delitos estejam predeterminados pela lei de maneira taxativa, sem reenvio a parâmetros extralegais, de modo a não permitir uma interpretação ampla, que admita um dilatado alcance segundo a vontade do intérprete. Da mesma forma, não deve haver imprecisão ou descrições dúbias: o proibido deve estar de expresso de forma clara.

A garantia da materialidade da ação exige que nenhum dano, por mais grave que seja, pode-se estimar penalmente relevante senão como efeito de uma ação. Os delitos devem se concretizar em ações humanas - materiais, físicas ou externas - empiricamente observáveis, passíveis de serem descritas pela lei penal. Necessária uma relação entre a causalidade entre a ação e o resultado, pois somente a ação externa é capaz de produzir uma modificação no mundo exterior qualificável de lesão. (FERRAJOLI, 2006, p. 440) Ordena, portanto, a precisão de um fato ofensivo, que tenha o condão de, além de infringir a norma, causar um dano social tal que obstrua a convivência social satisfatória. Impõe-se, dessa feita, a observância ao princípio da ofensividade (ou lesividade) ${ }^{7}$.

A legalidade refere-se, igualmente, à pena, a qual, por intermédio de um processo democrático, deve ser adequada ao delito em relação à natureza e à sua gravidade, bem como as ponderações relativas ao próprio agente infrator. O princípio da proporcionalidade é um corolário dos princípios da legalidade e da retributividade e como tal acarreta "a possibilidade de uma lei ser reconhecida ilegal por vício de excesso, manifestando, pois, que também contra lei em tese, e não somente em relação a fato, atua o princípio da proporcionalidade. Sua função, nesse caso, passa a ser limitativa da atividade legiferante". (SCHMIDT, 2001, p. 277)

Conforme SANTOS (2008, p. 27) divide-se em três subprincípios: "o princípio da adequação (Geeignetheit), o princípio da necessidade (Erforderlichkeit) e o princípio da proporcionalidade em sentido estrito, também chamado de princípio da avaliação

\footnotetext{
7 Funções proibitivas: a) de uma atitude interna - as aspirações, desejos e sentidos do autor, por faltar-lhe a exterioridade não podem constituir fundamento de um tipo penal; b) de uma conduta que não exceda âmbito o próprio autor - seriam as hipóteses dos atos preparatórios e da autolesão, haja vista a ausência da alteridade (bilateralidade); c) de simples estados ou condições existenciais - o direito penal requer uma desvalor de ação, estando vedado o direito penal de autor; e, derradeiramente, d) de condutas desviadas que não afetem qualquer bem jurídico - critério delineador da lesividade, revelando e demarcando a ofensa. (BATISTA, 2002, p. 92-94)
} 
(abwägungsgebote)". Interessa avaliar o princípio em sentido estrito - juízo de ponderação - de modo que o meio utilizado (pena) não sobreleve o fim a que se propôs.

“O princípio em causa está presente na norma penal incriminadora ao fixar in abstrato, a medida da pena. E depois se faz presente no momento da aplicação. Em que é fundamental, ao lado da intensidade objetiva da ofensa, a maior ou menor culpabilidade com que se houve o agente". (LUISI, 2003, p. 184) Previsões sancionatórias através de penas fixas, estão em dissonância com a feição constitucional do Direito Penal, vez que a existência de uma margem de discricionariedade judicial (vinculada e limitada por critérios legais) "permite que a pena concreta apresente-se, também, proporcional à real gravidade do delito, dentro da inteira gama de comportamentos, subsumíveis ao tipo incriminador”. (GOMES, 2003, p. 159)

O princípio da legalidade, dessa feita, deixa de ser considerado sob um ponto de vista meramente formal (legalidade lata ou vigência). Um Direito penal democrático exige a descrição clara e taxativa da conduta criminosa para que sejam limitados os espaços de discricionariedade judicial. Requer-se a sua releitura em conformidade com um direito penal secularizado, do qual decorre a impossibilidade do chamado direito penal de autor, independentes de lesividade ou ofensividade.

\section{TERRORISMO NA PERSPETIVA DO DIREITO BRASILEIRO}

Os atentados terroristas aos edifícios do World Trade Center, em Nova Iorque e ao prédio do Pentágono, em Washington, representam um marco histórico, com repercussão internacional. A partir de então, o terrorismo alcançou uma ampla e constante exposição do início do século XXI. Esse novo ${ }^{8}$ terrorismo apresenta-se como uma ameaça transnacional, impondo-se de forma capaz de propagar o medo em todos os cantos do mundo.

Com o fenômeno da globalização, "o terrorismo, antes interessando mais ao direito interno e dirigido a alvos de projeção meramente nacionais, em virtude dessa mesma globalização se transformou, passando a se colocar como força contra-hegemônica em face do papel tradicionalmente hegêmonico do Estado". (GUIMARÃES, 2007, p. 107)

Inicialmente, cumpre-se apontar as dificuldades de um significado uníssono de terrorismo. Jeffrey Record aponta que "um estudo de 1998 contou 109 definições de terrorismo,

\footnotetext{
${ }^{8}$ Inobstante a disseminação internacional decorrente dos ataques de 11 de setembro, o terrorismo não é um fenômeno novo. A Liga das Nações propôs um esboço de convenção internacional em 1937 que definia terrorismo como: "Todo ato direcionado contra um Estado com intenção calculada de criar um estado de terror na mente de uma pessoa em particular ou de um grupo de pessoas particulares ou do público em geral”.
} 
que cobriam um total de 22 elementos diferenciais e mais tantas outras datações diferentes sobre o início do terrorismo enquanto prática”. Ainda, segundo Walter Laquear (apud ALMEIDA, BAZZANO, 2014, p. 81), "a única característica geralmente aceita sobre o terrorismo é a que envolve violência e a ameaça do uso de violência".

Não há uma convenção internacional que traga uma definição universal de terrorismo ${ }^{9}$, isso dá por ser um terrorismo um fenômeno que adota múltiplas formas, pela subjetividade de muitos dos critérios empregados, pela variedade de motivações dos atos terroristas a depender da época histórica e da ideologia dominante e pela diversidade dos elementos presentes em um ato terrorista. (CRETELLA NETO, 2009, p. 166)

FERNANDES (2014, p. 403), diante da diversidade de conceitos, especificou as características fundamentais do terrorismo: “a) uso da violência; b) o atingimento de pessoas inocentes; c) a finalidade ideológica ou política; d) a difusão do medo como objetivo". O terrorismo, portanto, caracteriza-se pela prática reiterada de atos de terror (mediante grave ameaça e violência) contra pessoas indeterminadas, transmitindo um sentimento de medo e insegurança, com a finalidade de desestabilizar ou destruir a ordem social e política vigente.

A partir do momento em que o terrorismo deixa de ser um fenômeno local ou regional e se torna uma preocupação de praticamente todos os países, passa-se a ser falar em terrorismo global, fazendo com que o tema mereça a atenção em países como o Brasil, em que não se detectam manifestações terroristas. (FERNANDES, 2014, p. 402)

A Constituição Federal de 1988, logo no art. $4^{\circ}$, inciso VIII, quando aborda os Princípios Fundamentais, determina que o Brasil, reger-se-á, em suas relações internacionais, pelo repúdio ao terrorismo. Em seguida, no artigo $5^{\circ}$, quando trata dos direitos e garantias fundamentais, mais especificamente em seu inciso XXXIX, dispõe que o terrorismo é considerado crime inafiançável, insuscetível de graça ou anistia ${ }^{10}$, por ele respondendo os mandantes, os executores e os que, podendo evitá-lo, se omitirem.

"Pela primeira vez uma Constituição Federal tratou a matéria de modo específico, ainda que sucintamente, porém empregando expressamente o termo em seu texto e, mais que isso,

\footnotetext{
9 “O que se observa é o emprego de uma abordagem em duas vertentes, pela qual são adotadas normas - na forma de convenções internacionais, leis nacionais e resoluções do Conselho de Segurança da ONU - que disciplinam determinadas manifestações específicas da atividade terrorista, e representam o enfoque jurídico, bem como uma condenação geral do terrorismo, o chamado discurso político sobre o terrorismo". (CRETELLA NETO, 2009, p. 131)

10 "Significa, portanto, que o legislador constituinte, depois de já ter repudiado expressamente o terrorismo, não se contentou apenas em manifestar seu desejo e incriminação de tal comportamento, mas foi além, especialmente ao equipará-los aos crimes hediondos para the prever conseqüências penais claramente mais gravosas". (GOMES, 2014, p. 359)
} 
alocando-o em posição de destaque, inserido que foi, repita-se, nos princípios, direitos e garantias fundamentais". (GUIMARÃES, 2007, p. 92) Com o comando constitucional, a doutrina pátria passa a discutir a tipificação do terrorismo. Segundo entendimento majoritário, não havia um tipo específico de terrorismo que atendesse ao mandado constitucional e que dispusesse de forma específica os elementos definidores dessa conduta criminosa.

FERNANDES (2014, p. 407) entende que o "terrorismo" está previsto no artigo $20^{11}$ bem como em outros dispositivos da Lei no 7.170/: "nesses artigos estão presentes, em regra, os elementos apontados como essenciais para a caracterização do terrorismo e, no art. 20, exige-se também a finalidade política”. A doutrina majoritária, ante a amplitude da expressão atos de terrorismo contida no dispositivo legal considerava a impossibilidade de considerá-lo como forma de tipificação da conduta, em razão da manifesta violação à taxatividade ${ }^{12}$.

A definição da conduta através da expressão "praticar atos de terrorismo" fica na dependência do que se compreende por "atos de terrorismo". Dessa forma, conclui FRANCO (p. 118-119) "vulnera-se, assim, o aspecto material do princípio nullum crimen sine lege (stricta)". No mesmo sentido, LEAL (2013, p. 79):

\begin{abstract}
Do ponto de vista técnico-jurídico, a redação confusa e ambígua deste dispositivo legal, parece-nos insuficiente para construir uma definição jurídica de terrorismo, como tipo penal autônomo. Por isso, como consequência da adoção do princípio da legalidade, cremos que ninguém poderá ser punido por este tipo de crime, enquanto uma lei específica não definir objetivamente o tipo de conduta denominada terrorismo. É preciso que a lei descreva, com precisão e de forma objetiva quais são as ações caracterizadoras de um possível tipo legal de terrorismo. Ou seja, o crime previsto no art. 20, caput, da LSN, não pode receber o nomem juris de terrorismo, principalmente para o fim de ser marcado com o rótulo de hediondez e de sofrer as consequências penais previstas na LCH.
\end{abstract}

MONTEIRO (2008, p. 134) leciona que "a noção de terrorismo continua sob incertezas doutrinárias sem definição legislativa", visto que "a lei utiliza um discutido nomen juris como definição legal do tipo". A expressão "atos de terrorismo" torna impossível a determinação do conteúdo da norma incriminadora e, portanto, não satisfaz a exigência constitucional da legalidade, mais especificamente a taxatividade da lei penal.

\title{
5 CONSIDERAÇÕES CRÍTICAS DOS TIPOS PENAIS DA LEI N. 13.260/16
}

\footnotetext{
${ }^{11}$ Art. 20. Devastar, saquear, extorquir, roubar, seqüestrar, manter em cárcere privado, incendiar, depredar, provocar explosão, praticar atentado pessoal ou atos de terrorismo, por inconformismo político ou para obtenção de fundos destinados à manutenção de organizações políticas clandestinas ou subversivas.

12 "Assim, é impossível, a partir da estrutura da norma incriminadora, estabelecer o conteúdo do que sejam tais atos; impossível, portanto, satisfazer a exigência constitucional de previsibilidade da punição, ínsita aos postulados da taxatividade e da anterioridade da lei penal”. (GOMES, 2014, p. 370)
} 
Foi a partir do ataque terrorista aos EUA que o terrorismo entrou na pauta dos problemas mundiais, tendo, como consequência, a exigência de que os ordenamentos jurídicos se adequassem a essa nova realidade através da adoção de medidas penais para punir os atos de terrorismo. Destaca-se a Resolução 1.373, do Conselho das Nações Unidas, trazendo em seus termos o repúdio ao terrorismo e a Convenção Interamericana contra o Terrorismo, reafirmando o compromisso dos Estados signatários de prevenir, reprimir e eliminar o terrorismo, bem como o seu combate através de uma cooperação internacional ${ }^{13}$.

“Em matéria de terrorismo o recurso à cooperação jurídica internacional qualifica-se como instrumento indispensável a garantir a eficácia na atividade de persecução, mas principalmente na sua prevenção". (BECHARA, 2014, p. 385)

O primeiro princípio básico da cooperação internacional, segundo o Manual de cooperação jurídica internacional relativa ao terrorismo é a criminalização das condutas. O Brasil assumiu, portanto, o compromisso internacional de prevenir e reprimir os atos de terrorismo no país $^{14}$. Atendendo ao comando constitucional e ao direito convencional, o legislador finalmente edita a Lei sobre o Terrorismo no Brasil. Originada do Projeto de Lei n ${ }^{\circ}$ 2016-F de 2015, de autoria do Poder Executivo, a Lei n ${ }^{\circ} 13.260$, de 16 de março de 2016, regulamentou o disposto no inciso XLIII do art. $5^{\circ}$ da Constituição Federal, disciplinando o terrorismo, tratando de disposições investigatórias e processuais e reformulando o conceito de organização terrorista, além de promover alterações legislativas.

\footnotetext{
${ }^{13}$ Pode-se apontar, como exemplos de ratificação do direito convencional o decreto $\mathrm{n}^{\mathrm{o}} 3.018$, de 06 de abril de 1999, promulga a Convenção para Prevenir e Punir os Atos de Terrorismo Configurados em Delitos Contra as Pessoas e a Extorsão Conexa, Quando Tiverem Eles Transcendência Internacional. Decreto n ${ }^{\circ} 66.520$, de 30 de abril de 1970 - Promulga a Convenção relativa às infrações e a certos outros atos cometidos a bordo de aeronaves.Decreto $\mathrm{n}^{\circ} 70.201$, de 24 de fevereiro de 1972 - Promulga a convenção ao apoderamento ilícito de Aeronaves.Decreto $\mathrm{n}^{\circ} 5.639$, de 26 de dezembro de 2005 - Promulga a Convenção Interamericana contra o Terrorismo, assinada em Barbados, em 3 de julho de 2012.Decreto $\mathrm{n}^{\circ}$ 5.650, de 26 de dezembro de 2005 Promulga a Convenção Internacional para supressão do financiamento do terrorismo, adotada pela AssembleiaGeral das Nações Unidas de 1999 e assinada pelo Brasil em 10 de novembro de 2001.Decreto $\mathrm{n}^{\circ}$ 4.394, de 26 de setembro de 2002 - Promulga a Convenção Internacional sobre a supressão de Atentados Terroristas com Bomba, com reserva ao parágrafo $1^{\circ}$ do artigo 20.

${ }^{14}$ Pode-se apontar, como exemplos de ratificação do direito convencional o decreto $\mathrm{n}^{\circ} 3.018$, de 06 de abril de 1999 , promulga a Convenção para Prevenir e Punir os Atos de Terrorismo Configurados em Delitos Contra as Pessoas e a Extorsão Conexa, Quando Tiverem Eles Transcendência Internacional. Decreto ${ }^{\circ} 66.520$, de 30 de abril de 1970 Promulga a Convenção relativa às infrações e a certos outros atos cometidos a bordo de aeronaves. Decreto $\mathrm{n}^{\circ} 70.201$, de 24 de fevereiro de 1972 - Promulga a convenção ao apoderamento ilícito de Aeronaves. Decreto no 5.639, de 26 de dezembro de 2005 - Promulga a Convenção Interamericana contra o Terrorismo, assinada em Barbados, em 3 de julho de 2012. Decreto $\mathrm{n}^{\circ}$ 5.650, de 26 de dezembro de 2005 - Promulga a Convenção Internacional para supressão do financiamento do terrorismo, adotada pela Assembleia-Geral das Nações Unidas de 1999 e assinada pelo Brasil em 10 de novembro de 2001. Decreto ${ }^{\circ}$ 4.394, de 26 de setembro de 2002 - Promulga a Convenção Internacional sobre a supressão de Atentados Terroristas com Bomba, com reserva ao parágrafo $1^{\circ}$ do artigo 20.
} 
A seguir será feita a análise crítica das condutas criminosas tipificadas pela Lei $\mathrm{n}$. 13.260/2016, avaliando-os sob o ponto de vista do princípio da legalidade estrita e do direito penal do inimigo.

O caput do artigo $2^{\text {o15 }}$ traz o que se pode entender por conceito de terrorismo. Inobstante as divergências doutrinárias e a inexistência de um conceito universal de terrorismo, o legislador nacional optou conceituar o terrorismo. Ainda que tenha suprido a lacuna da ausência de uma definição legal, nota-se evidente violação ao princípio da taxatividade: No que consiste terror social? Generalizado importa qual tipo de abrangência?

O princípio da taxatividade impõe uma técnica legislativa que permite a máxima objetividade do processo de concretização judicial do tipo de delito, a limitação das cláusulas gerais e dos elementos normativos do tipo através do reenvio à valoração social e normas cuja existência e cujo conteúdo são empiricamente controláveis. (FREITAS, 2002. p. 37)

Observa-se, portanto, que a exigência clareza e certeza da lei é indispensável para "evitar formas diferenciadas, e, pois, arbitrárias na sua aplicação, ou seja, para reduzir o coeficiente de variabilidade subjetiva na aplicação da lei”. (LUISI, 2008, p. 24)

No conceito de terrorismo o legislador determina a necessidade de a conduta expor a perigo a pessoa, patrimônio, paz pública ou incolumidade pública. Trata-se de um crime de perigo, esse perigo é concreto ou abstrato? Enquanto os crimes de perigo concreto exigem a prova de colocação em risco do bem jurídico tutelado, os crimes de perigo abstrato prescindem dessa comprovação. Na forma do princípio da lesividade, somente há a configuração de um ilícito penal quando o interesse já selecionado (princípio da reserva legal) sofre uma ofensa efetiva, que represente um dano ou um perigo concreto.

Assevera MORAIS DA ROSA (2006, p. 134):

O Poder Legislativo encontra, ainda, a barreira material dos Direitos Fundamentais em
duplo sentido. Partindo-se do Direito Penal como última ratio (princípios da lesividade,
necessidade e materialidade), a regulamentação de condutas deve se ater à realização dos
Princípios Constitucionais do Estado Democrático de Direito, construindo-se, dessa
forma, um modelo minimalista de atuação estatal que promova, de um lado, a realização
destes Princípios e, de outro, impeça suas violações, como de fato ocorre com a explosão
legislativa penal contemporânea, quer pelas motivações de manutenção do status quo,
como pela 'Esquerda Punitiva'.

15 Terrorismo consiste na prática por um ou mais indivíduos dos atos previstos neste artigo, por razões de xenofobia (aversão a coisas ou pessoas estrangeiras), discriminação ou preconceito de raça, cor, etnia e religião, quando cometidos com a finalidade de provocar terror social ou generalizado, expondo a perigo pessoa, patrimônio, a paz pública ou a incolumidade pública. 
No parágrafo $1^{\mathrm{o}}$ são definidos os atos de terrorismo ${ }^{16}$.

Primeiramente, conforme é possível observar-se no inciso I, há clara transgressão ao princípio da proporcionalidade, vez que pune com a mesma pena (reclusão de 12 a 30 anos) a conduta de usar ou ameaçar usar explosivos, gases tóxicos, venenos, conteúdos biológicos, químicos, nucleares ou outros meios capazes de causar danos ou promover destruição em massa. Condutas com gravidades distintas - efetivamente usar um explosivo ou apenas ameaçar usá-los com penas idênticas. Ainda, fazendo uma interpretação sistemática com o Código Penal, a conduta descrita tem a mesma pena do delito de homicídio qualificado. Ou seja, um crime de perigo tem a pena mais alta que um crime de dano à vida humana.

Avaliando a proporcionalidade sob o âmbito da legitimidade interna do ordenamento jurídico SCHMIDT (2001, p. 295) afirma que resta claro que "a proporcionalidade da sanção penal é tomada a partir de uma interpretação comparativa entre duas situações: caso elas sejam idênticas ou semelhantes, devem receber tratamento idêntico ou semelhante, caso sejam elas diferentes, devem receber tratamento diferenciado, na medida de sua desigualdade".

Em um segundo momento, ainda no inciso I, é importante apontar: o que seriam outros meios capazes de causar danos ou promover destruição em massa? Afronta-se a taxatividade da lei penal, pois não se atende ao comando da clareza, certeza e precisão, pelo contrário, o legislador valeu-se de expressões vagas e indeterminadas, permitindo variadas e contrastantes interpretações. “Assim, quanto mais imprecisão (do tipo penal), menos limitação (ao poder punitivo estatal) e, por conseguinte, menos garantia". (PINHO, 2006, p. 84)

No inciso $\mathrm{V}$ nota-se também a transgressão à proporcionalidade. A tentativa de homicídio ou de lesão corporal está submetida à mesma pena (reclusão de 12 a 30 anos), não havendo uma relação proporcional entre a gravidade da conduta e da sanção. Ainda, a tentativa de homicídio prevista na lei tem pena igual ao homicídio qualificado consumado, tipificado no Código Penal. Para combater os atos terroristas, a proporcionalidade passa a ser tomada pela ideia de que quanto maior o perigo, maior é a sanção, antecipando-se drasticamente o momento da intervenção penal para antes da ocorrência de um resultado.

\footnotetext{
${ }^{16}$ I - usar ou ameaçar usar, transportar, guardar, portar ou trazer consigo explosivos, gases tóxicos, venenos, conteúdos biológicos, químicos, nucleares ou outros meios capazes de causar danos ou promover destruição em massa; II e II vetados; IV - sabotar o funcionamento ou apoderar-se, com violência, grave ameaça a pessoa ou servindo-se de mecanismos cibernéticos, do controle total ou parcial, ainda que de modo temporário, de meio de comunicação ou de transporte, de portos, aeroportos, estações ferroviárias ou rodoviárias, hospitais, casas de saúde, escolas, estádios esportivos, instalações públicas ou locais onde funcionem serviços públicos essenciais, instalações de geração ou transmissão de energia, instalações militares, instalações de exploração, refino e processamento de petróleo e gás e instituições bancárias e sua rede de atendimento; V - atentar contra a vida ou a integridade física de pessoa.
} 
Por fim, atentar contra a vida ou integridade de pessoa importa em relevante questionamento: estaria a lei se referindo a uma única pessoa ou o ataque deve visar pessoas indeterminadas? Não está clara essa tipificação, o que dá margens a interpretações distintas.

A definição precisa da conduta criminosa é uma garantia salutar, pois é a partir dela que se define o objeto da investigação e o que deve ser submetido à verificação probatória, para então, traduzir-se em elementos concretos para uma condenação. Afastam-se as garantias penais e processuais penais, dando ao inimigo o tratamento de não sujeito.

A Lei n. 13.260/16 utiliza-se feita, de técnicas legislativas para a criminalização do delito que são caracterizadas, essencialmente, pela antecipação da punibilidade:

\begin{abstract}
A tentativa do delito, que supõe uma antecipação a respeito da consumação delitiva. A incriminação autônoma de condutas que, em si, não são mais que atos preparatórios de outros delitos. A incriminação de atos preparatórios ou de tentativa de delito como se fossem delitos consumados. Os chamados delitos obstáculo, que consistem na incriminação de premissas idôneas de outros delitos ulteriores. Ou a técnica dos delitos de posse (em que se sanciona a detenção ou a posse de um objeto geralmente perigo: armas de fogo, drogas, substâncias inflamáveis) ou os delitos de organização ou status (nos quais se sanciona o pertencimento a um grupo criminoso ou bando armado). (grifo no original) (POLAINO-ORTIS, 2014, p. 87-88)
\end{abstract}

Essas técnicas antecipatórias podem ser observadas no art. $2^{\circ}$, parágrafo $1^{\circ}$, incisos I e $\mathrm{V}$, como a incriminação de atos preparatórios, dos delitos-obstáculos e a técnica dos delitos de posse. Segue-se o paradigma da colocação em perigo de bens jurídicos em substituição ao paradigma da efetiva lesão material a esses mesmos bens jurídicos.

Por fim, ainda sobre o artigo $2^{\circ}$ é importante ressaltar que o tipo exige dois elementos subjetivos especiais - por razões de xenofobia, discriminação ou preconceito de raça, cor, etnia e religião e ainda a finalidade de provocar terror social ou generalizado. Para a configuração do delito, além da prática das condutas descritas no $\S 1^{\circ}$, exigem-se as finalidades específicas previstas no caput, além da colocação em risco de pessoa, patrimônio, paz pública ou a incolumidade pública. Daí decorrem duas conclusões, diametralmente opostas: dada a elasticidade dos conceitos qualquer conduta poderá ser configurada como terrorismo a depender da interpretação ou, ante a exigência de duas finalidades especiais e da criação de risco, raramente uma conduta será configurada como terrorismo.

ZAFFARONI (2007, p. 186) alerta para o perigo de criar tipos penais de terrorismo, que costumam gerar efeitos paradoxais: "Antes de mais nada, porque é comum que firam o princípio da legalidade estrita, e com isso possam ser declarados inconstitucionais. Em segundo lugar, porque todos pretendem incorporar elementos subjetivos". 
$\mathrm{O}$ art. $3^{\circ}$, por sua vez, prevê a conduta criminosa de "promover, constituir, integrar ou prestar auxílio, pessoalmente ou por interposta pessoa, a organização terrorista", impondo pena de reclusão, de cinco a oito anos, e multa. Não há a definição de organização terrorista, deixando uma amplitude ao intérprete, em clara violação à taxatividade da lei penal.

Nota-se, ainda, que a participação, que segundo o paradigma do direito penal tradicional é meramente acessória à conduta principal, aqui recebe o mesmo tratamento, pois é colocada conjuntamente com os verbos promover, constituir e integrar. Ou seja, aquele que presta auxílio à organização terrorista terá o mesmo tratamento de quem a integra ou constitui.

$\mathrm{O}$ artigo $5^{\circ}$ tipifica a conduta de "realizar atos preparatórios de terrorismo com o propósito inequívoco de consumar tal delito", sendo apenado com a pena correspondente ao delito consumado, diminuída de um quarto até a metade ${ }^{17}$. É possível notar a antecipação da punibilidade, vez que a tentativa só é punível quando iniciada a execução. Os atos preparatórios podem ser punidos, desde que constituam um tipo penal autônomo e, como tal, descritos em lei penal clara e precisa quanto ao conteúdo da conduta criminosa, caso contrário, a sua punição representa uma manifesta afronta ao primado da lesividade.

Segundo a ofensividade, somente os comportamentos externos que causem lesão ou perigo concreto de lesão a bem jurídico de terceiros podem ser objeto de punição. As condutas internas, não podem ser sancionadas. Ainda, aquelas condutas que se restringem ao âmbito do próprio autor, e também as externas que não causem lesão ou perigo efetivo de lesão, por falta de lesividade e alteridade não legitimam a intervenção penal ${ }^{18}$.

O tipo, ainda, fornece uma ampla discricionariedade ao aplicador para avaliar o que entende como atos preparatórios, o que pode levar a incriminação de simples estados ou condições existenciais, de acordo com os interesses punitivos do Estado. Abre-se as portas para um direito penal de autor, ou seja, aqueles taxados de terroristas serão facilmente enquadrados no tipo, haja vista sua abertura semântica ${ }^{19}$. "O fenómeno terrorista inflacionou a teoria do Direito penal

\footnotetext{
${ }^{17}$ No $\S 1^{\circ}$ do artigo $5^{\circ}$, o legislador traz as modalidades equiparadas: I - recrutar, organizar, transportar ou municiar indivíduos que viajem para país distinto daquele de sua residência ou nacionalidade; ou II - fornecer ou receber treinamento em país distinto daquele de sua residência ou nacionalidade.

18 "Se o Direito Penal somente está legitimado a intervir diante da produção efetiva de um dano (princípio da ofensividade), é consequência que esse dano apenas pode ser produzido por uma concreta ação humana, palpável, visível e empiricamente demonstrável (princípio da materialidade da ação)”. (PINHO, 2006, p. 96)

19 “A leis indeterminadas em seu conjunto por sua ambigüidade deliberada não permitem conhecer precisamente que condutas concretas são punidas, o que implica, de modo implícito, a renúncia do legislador à sua missão de definição dos comportamentos delitivos e uma remissão ao juiz para que este cumpra com tal labor". (BUSATO, 2003, p. 49)
} 
preventivo subjugado à lógica da guerra preventiva e transformou o Direito penal do terrorismo em Direito penal do inimigo". (VALENTE, 2010, p. 26)

Esse Direito penal preventivo prescinde de qualquer resultado concreto - seria uma violação aos direitos dos cidadãos, pois trata o cidadão injustamente como o inimigo por intermédio de uma intervenção penal mesmo que ausente um comportamento (externo) capaz de causar uma perturbação. Nesse sentido as lições de VALENTE (2010, p. 100):

Podemos avançar que o fenómeno do terrorismo serviu de base para a implementação de uma esquizofrenia belicista do sistema integral penal, gerando a tese da criação de um Direito penal do inimigo com amarras scmittiana e heideggeriana, que consideramos ser mais a implementação de um sistema integral penal do inimigo devido à desorganizada e desorientada (ou inexistente) política criminal. A política criminal em curso não se centra no rosto dos seres humanos.

Por fim, o último tipo penal, o financiamento ao terrorismo vem descrito no art. $6^{021}$.

O tipo penal, no caput traz oito verbos e no parágrafo único mais oito, com condutas distintas que variam desde um favorecimento real até lavagem de dinheiro. A variedade de verbos e de condutas típicas é um claro exemplo do afã legislativo de punição, prescindindo-se de uma técnica legislativa mais adequada, que atendesse à legalidade, em sentido estrito.

Ora, o princípio da legalidade, dirigido ao legislador e ao aplicador da norma, "deve impregnar-se na linha de construção de qualquer um espaço (e tempo) penal: seja nacional, seja europeu, seja Mercosul, seja transnacional”. (VALENTE, 2014, p. 75).

Segundo MUÑOZ CONDE (apud VALENTE, 2010, p. 21), o ataque terrorista de 11 de setembro gerou um aumento da violência e da luta conta o terrorismo, de tal modo que:

(...) está a modificar a imagem do Direito penal de Estado de Direito, como um Direito respeitoso das garantias e dos direitos fundamentais do cidadão, transformando-se em uma imagem de um Direito penal bélico, um Direito penal do inimigo (expressão utilizada e desenvolvida por Jakobs...), em que as garantias praticamente desaparecem para

\footnotetext{
${ }^{20}$ Os traços característicos do Direito penal do inimigo estão claros: o adiantamento da punibilidade a um estágio anterior ao resultado material ao bem jurídico para evitar que o perigo se converta em algo maior, passa-se da perspectiva da reação (retrospectiva) para a prevenção de um fato futuro (perspectiva prospectiva); restringe-se a esfera de liberdade dos sujeitos que se associam e, por fim, sanciona-se esse delito antecipado como delito consumado. POLAINO-ORTIS (2014, p. 103-104)

${ }^{21}$ Receber, prover, oferecer, obter, guardar, manter em depósito, solicitar, investir, de qualquer modo, direta ou indiretamente, recursos, ativos, bens, direitos, valores ou serviços de qualquer natureza, para o planejamento, a preparação ou a execução dos crimes previstos nesta Lei: Pena - reclusão, de 15 a 30 anos. No parágrafo único o as modalidades equiparadas: quem oferecer ou receber, obtiver, guardar, mantiver em depósito, solicitar, investir ou de qualquer modo contribuir para a obtenção de ativo, bem ou recurso financeiro, com a finalidade de financiar, total ou parcialmente, pessoa, grupo de pessoas, associação, entidade, organização criminosa que tenha como atividade principal ou secundária, mesmo em caráter eventual, a prática dos crimes previstos nesta Lei.
} 
converter-se exclusivamente em um instrumento que procura toda a segurança cognitiva, por cima de qualquer outro valor ou direito fundamental.

A preocupação dos países com os ataques terroristas tem demandado uma legislação antiterrorista que nada mais é que o expoente máximo do Direito Penal do Inimigo, sendo a Lei 13.260/16 um claro exemplo dessa realidade, vez que é composta por um conjunto de tipos penais que constituem criminalização em estágio prévio a lesões de bens jurídicos e que estabelecem sanções desproporcionalmente altas em tipos penais cuja descrição prescinde da necessária técnica, ou seja, sem certeza, clareza e determinação. Nada justifica, nem mesmo a busca por segurança e a defesa de perigos, a renúncia às garantias e aos direitos fundamentais.

\section{CONSIDERAÇÕES FINAIS}

Não se questiona, aqui, a gravidade do fenômeno terrorista, tampouco a sua projeção internacional. Não há dúvidas da necessidade de uma Lei viesse efetivamente a abarcar os elementos caracterizadores do terrorismo, sobretudo levando-se em conta que o art. 20 da Lei n. 7170/83, ao referir-se a atos de terrorismo, não os definiu a contento, permitindo, ante sua vagueza e indeterminação diferentes e conflitantes entendimentos.

Contudo, a internacionalização do fenômeno e sua gravidade não são aptos a justificar as afrontas aos princípios constitucionais do Estado Democrático de Direito. A Lei n. 13.260/16 viola os princípios integrantes da legalidade estrita (taxatividade, ofensividade, proporcionalidade), justificando referidas transgressões com um discurso de prevenção de riscos e combate ao inimigo, com o fim de legitimar a expansão do poder punitivo.

Não há como não observar que o discurso de guerra e combate ao inimigo - aqui eleito o terrorista - estão reproduzidos na Lei n. 13.260/16 - bem como é possível apontar as características da doutrina do direito penal do inimigo: a) punição antecipada, seja pelos crimes de perigos abstrato, seja pela punição dos atos preparatórios; b) penas evidentemente desproporcionais; c) flexibilização das garantias penais e processuais penais (sobretudo a garantia da legalidade estrita); e d) legislação de combate, marcada pela prevenção de riscos.

Nesse modelo, a intervenção penal passa a cumprir o papel de prevenir riscos e tranquilizar a sociedade. Volta o olhar para o outro, eleito como o inimigo, justificando-se a barbárie. Parte-se da convicção ideológica de que "a causa que se defende é tão justa, e a do 
adversário é tão terrível, que todos os meios para conquistar a vitória e evitar a derrota não só são válidos como necessários" (HOBSBAWM, 2007, p. 127).

O princípio da legalidade exerce uma importante função de segurança e garantia, uma vez que impõe ao legislador, quando da elaboração dos tipos penais e das sanções correspondentes deverá conter máximo de determinação quanto ao seu alcance, de tal modo que se faça a descrição clara e precisa das condutas criminosas, que as penas sejam proporcionais à gravidade do delito e que a sua aplicação esteja condicionada à ocorrência de uma lesão grave ou um perigo concreto de lesão ao bem jurídico tutelado.

Os atos terroristas são uma ameaça a qualquer sociedade. Porém, o problema do terrorismo é, antes de tudo, um problema política o que demonstra a incapacidade do Direito penal para contribuir para controlar esse fenômeno. "A resposta é bastante óbvia: se ninguém faz nada, o direito penal nada pode fazer; se delitos são cometidos, seu responsáveis devem ser individualizados, detidos, processados, julgados, condenados e levados a cumprir pena. É isso que o direito penal pode fazer". (ZAFFARONI, 2007, p. 135)

Nessa guerra contra o terrorismo, em tempos de Direito penal bélico e de combate ao inimigo, caberá ao Direito penal exercer o seu papel democrático: controlar o poder punitivo e proteger o Estado Democrático de Direito contra a política penal de emergência.

\section{REFERÊNCIAS}

ALMEIDA, Álvaro Okura de; BAZZANO, Ariana. In. FERNANDES, Antonio Scarance; ZILLI, Marcos. (Org) Terrorismo e Justiça Penal. Reflexões sobre a Eficiência e o Garantismo. Belo Horinzonte: Editora Fórum, 2014. p. 35-71.

BATISTA, Nilo. Introdução Crítica ao Direito Penal Brasileiro. 8. ed. Rio de Janeiro: Revan, 2002.

BECCARIA, Cesare. Dos delitos e das penas. São Paulo: Martins Fontes, 1991.

BECHARA, Fábio Ramazzini. In. FERNANDES, Antonio Scarance; ZILLI, Marcos. (Org) Terrorismo e Justiça Penal. Reflexões sobre a Eficiência e o Garantismo. Belo Horizonte: Editora Fórum, 2014. p. 381-400.

BEDIN, Gilmar Antonio. In. BEDIN, Gilmar Antonio. (Org). Estado de Direito, Jurisdição Universal e Terrorismo. Levando o Direito Internacional à Sério. Ijuí: Editora Ijuí, 2009. p. 1336.

BOZZA, Fábio da Silva. Uma análise crítica da prevenção geral positiva no funcionalismo de Günther Jakobs. Revista Brasileira de Ciências Criminais. São Paulo: Editora Revista dos Tribunais. n. 70, jan.-fev. 2008. 
BUNG, Jochen. Direito penal do inimigo como teoria da vigência da norma e da pessoa. Trad. Helena Regina Lobo da Costa. Revista Brasileira de Ciências Criminais. São Paulo: Editora Revista dos Tribunais. n. 62, nov/dez. 2006.

BUSATO, Paulo César. Direito Penal. Parte Geral. São Paulo: Editora Atlas, 2013.

CRETELLA NETO, José. In. BEDIN, Gilmar Antonio. (Org). Estado de Direito, Jurisdição Universal e Terrorismo. Levando o Direito Internacional à Sério. Ijuí: Editora Ijuí, 2009. p. $123-221$.

FERRAJOLI, Luigi. Direito e razão: teoria do garantismo penal. Trad. Ana Paula Zomer et. al. São Paulo: Editora Revista dos Tribunais, 2002.

FERNANDES, Antonio Scarance. In. FERNANDES, Antonio Scarance; ZILLI, Marcos. (Org) Terrorismo e Justiça Penal. Reflexões sobre a Eficiência e o Garantismo. Belo Horinzonte: Editora Fórum, 2014. p. 401-424.

FRANCOS, Alberto Silva. Crimes Hediondos. 7. ed. São Paulo: RT, 2011.

FREITAS, Ricardo de Brito A. P. As Razões do Positivismo Penal no Brasil. Rio de Janeiro: Lumen Juris, 2002.

GOMES, Mariângela Gama de Magalhães. O princípio da proporcionalidade no Direito Penal. São Paulo: Editora Revista dos Tribunais, 2003.

In. FERNANDES, Antonio Scarance; ZILLI, Marcos. (Org) Terrorismo e Justiça Penal. Reflexões sobre a Eficiência e o Garantismo. Belo Horinzonte: Editora Fórum, 2014. p. 357-379.

GRECO, Luís. Sobre o chamado direito penal do inimigo. Revista Brasileira de Ciências Criminais. São Paulo: Editora RT. n. 56, set.-out. 2005. p. 80-112.

GUIMARÃES, Marcelo Ovidio Lopes. Tratamento Penal o Terrorismo. São Paulo: Quartier Latin. 2007.

HOBSBAWN, Eric. Globalização, Democracia e Terrorismo. São Paulo: Companhia das Letras, 2007.

JAKOBS, Günther. Direito penal do inimigo. Noções e críticas. Porto Alegre: Livraria do Advogado, 2008.

Fundamentos do Direito Penal. Trad. André Luís Callegari. São Paulo: Revista dos Tribunais, 2003.

LEAL, João José. Crimes Hediondos: a Lei 8.072 como expressão do direito penal da severidade. $2^{a}$ ed. Curitiba: Juruá, 2003.

LISZT, Franz Von. Tratado de Direito Penal Alemão. Trad. José Higino Duarte Pereira. Campinas: Russel Editores, 2003. Tomo I. 
LUHMANN, Niklas. Sociologia do Direito I. Trad. Gustavo Bayer. Rio de Janeiro: Edições Tempo Brasileiro, 1983.

LUISI, Luiz. Os princípios constitucionais penais. 2. ed. Porto Alegre: Sergio Antonio Fabris Editor, 2003.

MELLIÁ, Manuel Cancio. Direito penal do inimigo. Noções e críticas. Porto Alegre: Livraria do Advogado, 2008.

MONTEIRO, Antônio Lopes. Crimes Hediondos: texto, comentários e aspectos polêmicos. $8^{\mathrm{a}}$ ed. São Paulo: Saraiva, 2008.

MORAIS DA ROSA, Alexandre. Decisão penal: a bricolage de significantes. Rio de Janeiro: Lumem Juris, 2006.

NEUMANN, Ulfried. Direito penal no inimigo. Trad. Antonio Martins. Revista Brasileira de Ciências Criminais. São Paulo: Editora Revista dos Tribunais. n. 69, nov/dez. 2007.

PINHO, Ana Cláudia Bastos de. Direito Penal e Estado Democrático de Direito: uma abordagem a partir do garantismo de Luigi Ferrajoli. Rio de Janeiro, Lumen Juris, 2006.

POLAINO-ORTIS, Miguel. Lições de Direito Penal do Inimigo. São Paulo: LiberArs, 2014.

PRITTWITZ, Cornelius. O Direito Penal entre Direito Penal de Risco e Direito Penal do Inimigo: tendências atuais em direito penal e política criminal. Trad. Helga Sabotta de Araújo. Revista Brasileira de Ciências Criminais. São Paulo: Editora Revista dos Tribunais. n. 47, mar.-abr. 2004.

ROXIN, Claus. Estudos de Direito Penal. 2. ed. Rio de Janeiro: Renovar, 2008.

SANTOS, Juarez Cirino dos. Direito Penal: parte Geral. 3. ed. Curitiba: ICPC; Lumem Juris, 2008.

SCHIMIDIT, Andrei Zenkner. O princípio da legalidade penal no Estado Democrático de Direito. Porto Alegre: Livraria do Advogado, 2001.

SILVA, Pablo Rodrigo Alflen da. Aspectos críticos do direito penal na sociedade do risco. Revista Brasileira de Ciências Criminais. n. 46, jan.-fev. 2004. p. 73-93.

VALENTE, Manuel Monteiro Gudes. Direito Penal do Inimigo e o Terrorismo: O "Progresso ao Retrocesso". Coimbra: Almedina, 2010.

TAVARES, Juarez. Teoria do Injusto penal. Belo Horizonte: Del Rey, 2000.

ZAFFARONI, Eugênio Raúl. O inimigo no direito penal. Rio de Janeiro: Revan, 2007. 